\title{
Environmental effects on bacterial diversity in the surface mucus layer of the reef coral Montastraea faveolata
}

\author{
Reia Guppy*, John C. Bythell \\ Division of Biology, Ridley Building, University of Newcastle, Newcastle upon Tyne NE1 7RU, UK
}

\begin{abstract}
Spatial and temporal variation in bacterial 16S rDNA diversity from healthy coral Montastraea faveolata (Ellis \& Solander, 1786) was investigated using denaturing gradient gel electrophoresis (DGGE). The microbial communities of the surface mucus layer (SML) were investigated at 5 sites in Tobago of varying water quality and proximity to the mainland. Presence/absence and band intensity data from DGGE profiles were used as a relative measure of diversity of the microbial community structure. Multivariate analyses using PRIMER software Version 6.1.5 (multidimensional scaling and analysis of similarity) showed that microbial communities associated with corals from within the same reef area were very similar $(p=0.093)$, that there were significant differences between sites $(p=0.001)$, and that SML communities were significantly different from the microbial community within the water column $(\mathrm{p}=0.001)$. No strong correlations between the SML bacterial community structure and measured water quality parameters were observed using a biota-environment matching routine within PRIMER (BIOENV). Strong seasonal effects were observed on tagged corals from sites that were re-sampled 6 times covering the wet and dry seasons. Although the SML of $M$. faveolata appears to support a distinct microbial community, this study shows that intraspecific temporal and spatial variation also exists, and reasons for these differences are explored.
\end{abstract}

KEY WORDS: Bacterial fingerprinting · $16 \mathrm{~S}$ rDNA · Denaturing gradient gel electrophoresis · DGGE · Coral mucus · Tobago

\section{INTRODUCTION}

Ecosystem function is dependent on microbial processes, and the effects of even small environmental changes may be reflected and magnified within the microbial community over a relatively short time span (Paerl et al. 2003, Manini et al. 2004). Coral reef ecosystems are undergoing unprecedented rates of change which may be linked to global climate change effects (Hoegh-Guldberg 1999, Harvell et al. 2002) as well as local and regional environmental impacts (Jordán-Dahlgren et al. 2005). The study of microbial diversity on coral reefs has concentrated largely on changes associated with coral diseases (e.g. Rosenberg $\&$ Ben-Haim 2002). A more diverse microbial community has been found in diseased versus healthy corals
(Bythell et al. 2002, Cooney et al. 2002, Frias-Lopez et al. 2002, Pantos et al. 2003), however it is not known to what extent this increased diversity reflects a cause and/or an effect of the disease process. Recent studies have focused on the microbial ecology of healthy corals, and the potential roles of coral-microbe interactions (Ritchie \& Smith 1997, Rohwer et al. 2001, Kellogg 2004, Klaus et al. 2005). However, few studies have attempted to follow the natural (e.g. temporal) changes in microbial community structure associated with healthy corals and those exposed to stressful environmental conditions (Klaus et al. 2005). Clearly, a better understanding of these relationships is crucial if we are to understand the mechanisms leading to the initiation and progression of disease and the associated impacts on coral populations. 
Various factors may influence the surface mucus layer (SML) bacterial community of corals (Brown \& Bythell 2005). These include (1) production of antimicrobial chemicals, (2) supply of bacteria from the water column, (3) environmental conditions, (4) mucus composition and production rates, which represent availability of carbon and nutrients as well as the dynamics of the SML as a physical barrier, entrapment surface and growth medium.

Although the SML of corals is believed to be a highly dynamic layer, it appears to support a distinct resident bacterial community rather than the result of passive settlement and entrapment of water-borne bacteria (Ritchie \& Smith 1995a, Santavy 1995, Frias-Lopez et al. 2002). Comparisons between the bacterial species diversity found in the surrounding water column and coral mucus show little to no overlap (Rohwer et al. 2001, Frias-Lopez et al. 2002). The formation, composition and rate of production of the SML in corals are not well understood, but vary considerably between coral species (Brown \& Bythell 2005). The bacterial community of corals is also dependent on host coral species (Rohwer et al. 2002), with spatially- and temporallydistant coral colonies of the same species hosting a more similar bacterial community than adjacent colonies of different species. It is highly likely that the bacterial community of the SML is controlled to some extent by the nature and composition of coral mucus secretion and this, in turn, is likely to vary in relation to environmental conditions and coral health (Brown \& Bythell 2005). Klaus et al. (2005) looked at the microbial communities along a human-induced environmental gradient within whole-tissue extracts of Montastraea annularis and Diploria strigosa using terminal restriction fragment length polymorphism (T-RFLP). Differences in microbial community structure were observed in $D$. strigosa, but no significant change was observed in $M$. annularis, suggesting differences in environmental effect on host-microbe association and/or the host response to environmental changes.

The present study investigated spatial and temporal changes in bacterial (16S rRNA gene) diversity associated with the coral SML at sites subject to various anthropogenic influences on water quality. The study specifically targeted the external SML environment, avoiding coral tissue or skeleton bacterial communities, since the SML community is most likely to respond to both external water quality conditions and internal effects on mucus production. We directly correlated the SML bacterial diversity with specific water quality variables. Bacterial diversity was visualized by denaturing gradient gel electrophoresis (DGGE), and resulting band intensities and presence/ absence data were used as a molecular fingerprint of the bacterial community.

\section{MATERIALS AND METHODS}

Sampling sites. Coral mucus was collected from the scleractinian coral Montastraea faveolata (Ellis \& Solander, 1786) in the southern Caribbean island of Tobago over the period June 2003 to February 2004, at 5 reef sites (Fig. 1). Four sites (Cathedral, Japanese

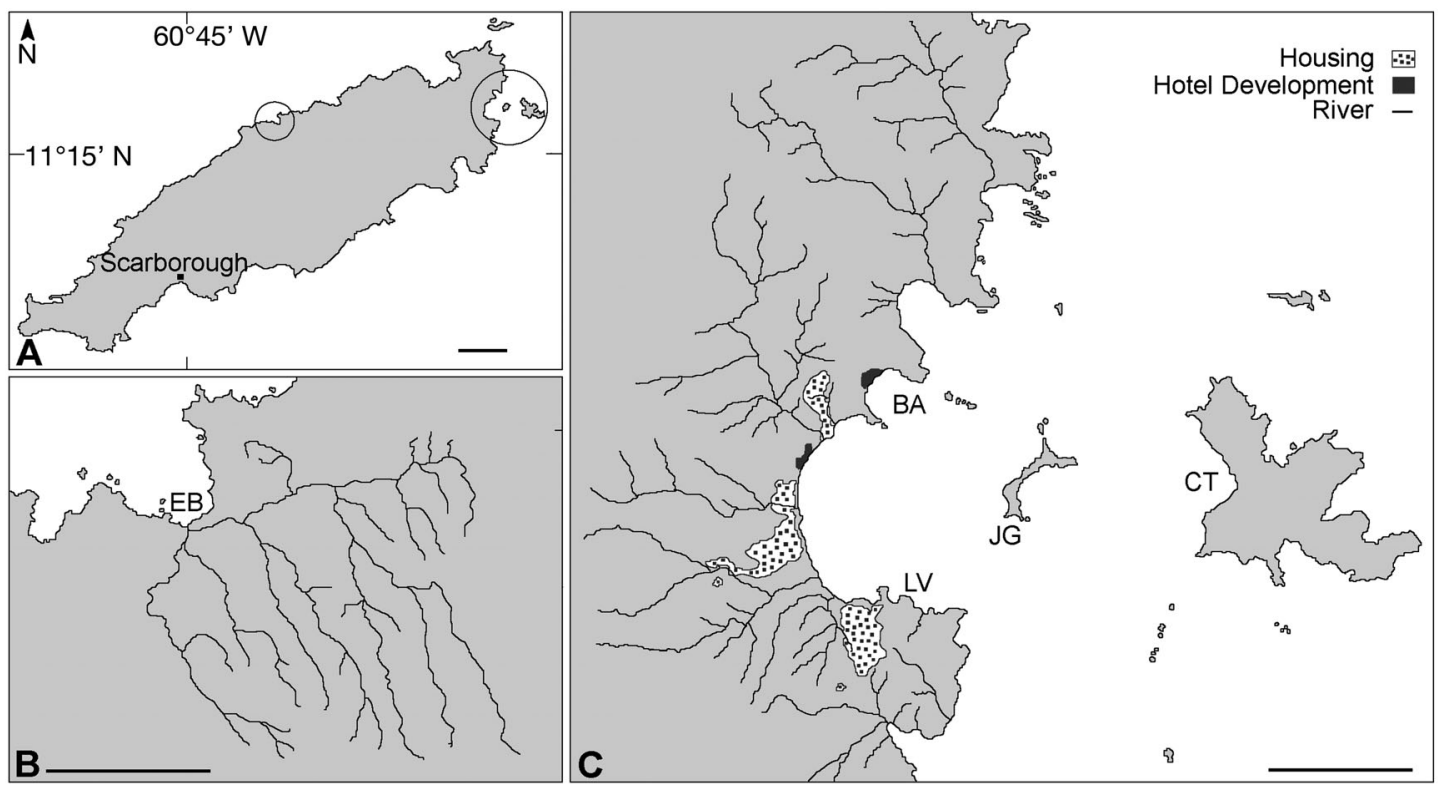

Fig. 1. Location of study sites. (A) Tobago; circles show (B) Englishman's Bay and (C) Speyside marine area. (B,C) Watersheds of Englishmen's Bay and Batteaux Bay, respectively. BA = Batteaux Bay; CT = Cathedral; EB = Englishman's Bay; JG = Japanese Gardens; LV = Lucy Vale. Scale bars $=1 \mathrm{~km}$ 
Gardens, Batteaux Bay and Lucy Vale) were within $1 \mathrm{~km}$ of each other within the Speyside proposed marine reserve area. A fifth site was located in Englishman's Bay, $\sim 9 \mathrm{~km}$ along the Northern coast of Tobago. Colonies $>1 \mathrm{~m}$ with well-developed skirt-like fringes were sampled within a $20 \mathrm{~m}$ radius at a given site, at depths ranging from 3 to $12 \mathrm{~m}$.

Bacterial collection. Mucus was collected using a method adapted from Harder et al. (2003), whereby approximately $20 \mathrm{~cm}^{2}$ of coral surface mucus layer was sampled using sterile cotton swabs $(\mathrm{n}=103)$, immediately placed in sterile universal tubes. Bacteria present in the surrounding seawater were sampled by passing $180 \mathrm{ml}$ of seawater through $0.22 \mu \mathrm{m}$ black polycarbonate syringe membrane filters $(n=23)$. Upon surfacing, filters were placed in sterile vials with $100 \%$ ethanol and all samples were transported on ice to the laboratory. Excess seawater was removed from swab samples by centrifuging $(5 \mathrm{~min}$ at $5000 \times g$ ), followed by gentle decanting and storage under $100 \%$ ethanol. Samples were stored at $-20^{\circ} \mathrm{C}$ until processing.

Water quality determination. Seawater samples $(150 \mathrm{ml})$ were collected from $1 \mathrm{~m}$ above the coral colonies, and filtered through Whatman GF/C glass fibre filters. Filters were placed in $90 \%$ acetone for $12 \mathrm{~h}$, and the concentration of chlorophyll a was determined following Strickland \& Parsons (1968). The filtrate was used to determine (1) phosphate ion $\left(\mathrm{PO}_{4}{ }^{3-}\right)$ concentrations following the colorimetric method of Parsons et al. (1984), and (2) nitrate + nitrite ion $\left(\mathrm{NO}_{\mathrm{x}}{ }^{-}\right)$concentrations by reduction in a cadmium-copper column following a volume-modified method of Strickland \& Parsons (1968). Dissolved $\mathrm{O}_{2}$, turbidity, total colifom, faecal, and E. coli data were obtained from IMA (2002).

DNA extraction for 16S rDNA analysis. DNA was extracted using a modified bacterial mini-prep method (Ausubel 1999). Swabs were freeze-dried and underwent an overnight chemical digestion $\left(0.1 \mathrm{mg} \mathrm{ml}^{-1}\right.$ proteinase $\mathrm{K}, 0.5 \% \mathrm{SDS}$ ) at $37^{\circ} \mathrm{C}$, followed by a $20 \mathrm{~min}$ incubation at $65^{\circ} \mathrm{C}$ with $10 \% \mathrm{w} / \mathrm{v}$ hexadecyltrimethylammonium (CTAB) in $0.7 \mathrm{M} \mathrm{NaCl}$. DNA was extracted using equal volumes of chloroform-isoamyl alcohol and centrifuged at $14000 \times g$ for $5 \mathrm{~min}$. The aqueous phase was extracted with phenol-chloroform-isoamyl alcohol and centrifuged $(14000 \times g$ for $5 \mathrm{~min})$. $0.65 \times$ volume isopropanol was added to the aqueous phase and centrifuged for $30 \mathrm{~min}$ at $15000 \times g$. The pellet was washed twice with $70 \%$ ethanol, recovered by centrifuging (16000 $\times g$ for $10 \mathrm{~min}$ ) and resuspended in $50 \mu \mathrm{l}$ TrisEDTA (TE) buffer (10 mM Tris-HCl, pH 7.4, $1 \mathrm{mM}$ ethylenediamine tetra-acetic acid (EDTA), pH 8.0). The DNA was purified by re-extracting with phenolchloroform-isoamyl alcohol, followed by 2 rounds of chloroform-isoamyl alcohol; $2 \times$ volume polyethylene glycol (PEG) 8000 (30\% w/v in 1.6 M NaCl) was added to the resulting aqueous phase and left at $4{ }^{\circ} \mathrm{C}$ for $1 \mathrm{~h}$ before centrifuging at $16000 \times g$ for $20 \mathrm{~min}$. The pellet was washed as above, and resuspended in $30 \mu \mathrm{l}$ TE. Filters were extracted using the method described by Cooney et al. (2002), and the DNA was precipitated with $2 \times$ volume PEG, washed and recovered as described above.

PCR amplification. A nested PCR approach was employed to amplify the bacterial 16S rDNA using primer sets previously used to analyse diseased coral bacterial communities (Pantos et al. 2003). Although a nested approach increases the amplicon bias (Suzuki \& Giovanni 1996), it was not possible to obtain usable product for DGGE analysis with only 1 PCR round. All reactions were performed using a Hybaid PCR Express thermal cycler. The first round of PCR was carried out using the primers pA (8F) 5'-AGA GTT TGA TCC TGG CTC AG-3' and pH' (1542R) 5'-AAG GAG GTG ATC CAG CCG CA-3' in a $50 \mu \mathrm{l}$ reaction containing $1.5 \mathrm{mM}$ $\mathrm{MgCl}_{2}, 0.2 \mathrm{mM}$ dNTP (PROMEGA), bovine serum albumin (BSA, $4 \mathrm{mg} \mathrm{hl}^{-1}$ ), $0.5 \mathrm{mM}$ of each primer, $2.5 \mathrm{U}$ of Taq DNA polymerase (QBiogene), incubation buffer, and $0.5 \mu$ l of template (no BSA was used with reactions containing water filter template). A touchdown PCR protocol following Cooney et al. (2002) was used. Products were purified and concentrated to $30 \mu \mathrm{l}$ using the QIAquick PCR purification kit (Qiagen), of which $0.5 \mu \mathrm{l}$ (35 to $60 \mathrm{ng}$ DNA) was used as template in the second PCR round for DGGE. The primers $\mathrm{pC}$ (341F) (5'-CCT ACG GGA GGC AGC AG-3') and pE' (928R) (5'-CCG TCA ATT CCT TTG AGT TT-3') were used, with the GC-rich sequence 5'-CGC CCG CCG CGC GCG GCG GGC GGG GCG GGG GCA CGG GGG G-3' incorporated in the forward primer pC at its 5 ' end to prevent complete disassociation of the DNA fragments during DGGE (Rölleke et al. 1996). A hotstart protocol was performed according to Cooney et al. (2002). The presence of good quality and size amplicons were determined by agarose gel electrophoresis $(1.6 \%(\mathrm{w} / \mathrm{v})$ agarose) after staining with ethidium bromide and visualised using a UV transilluminator.

DGGE analysis. DGGE was carried out using the D-Code universal mutation detection system (Bio-Rad). Nested PCR products were used to obtain DGGE fingerprints, since reproducible DGGE fingerprints were obtained with this technique. Products were cleaned using the QIAquick PCR purification kit (Qiagen) and eluted with $50 \mu \mathrm{l}$ of molecular-grade water. DNA was quantified using a Jenway 6405 UV spectrophotometer, and approximately $1000 \mathrm{ng}$ of DNA was used in the DGGE gels. Products were resolved on $6 \%(\mathrm{w} / \mathrm{v})$ polyacrylamide gels containing a 30 to $60 \%$ denaturing gradient for $5 \mathrm{~h}$ at $60^{\circ} \mathrm{C}$ at a constant voltage of $150 \mathrm{~V}$. Gels were stained with Sybr Green 1 (Sigma) for $45 \mathrm{~min}$ and visualised with a UV transilluminator. 
Statistical analysis. Bacterial operational taxonomic units (OTUs) were defined from DGGE band-matching analysis using BioNumerics 3.5 (Applied Maths BVBA), with the inclusion of uncertain bands (based on intensity sensitivity $>1 \%$ ). Tolerance and optimisation for band-matching was set at $1 \%$. Matrices of OTU versus sample were generated using both presence/ absence and band intensity data, using marker lanes for between-gel comparisons. Multidimensional scaling (MDS), analysis of similarity (ANOSIM), SIMPER and RELATE functions were used to determine similarity in DGGE profiles between samples using PRIMER software (Clarke \& Warwick 1994). Biota-environmental matching (BIOENV) was used to correlate multivariate DGGE profiles with environmental variables and similarity percentages (SIMPER) were used to determine OTUs contributing most to the dissimilarity between samples. Temporal and spatial effects on bacterial diveristy (Shannon-Wiener $H^{\prime}$ ) were analyzed in Minitab (Version 14) by 1-way ANOVA and MANOVA. significantly different using Simpson's index (1-D) (Table 1). MDS ordination of DGGE band intensity profiles shows a greater similarity within than between sites (Fig. 2B), and differences between sites were highly significant (1-way ANOSIM, R $=0.97, \mathrm{p}=$ 0.001). All possible pairwise comparisons showed significant differences between sites $(p<0.03)$. Using the SIMPER function in PRIMER, all sites had an average dissimilarity in bacterial OTUs $>45 \%$, with the most dissimilar sites being Cathedral and Englishman's Bay $(68.1 \%)$ and the least dissimilar being Lucy Vale and Japansese Gardens (46.4\%). This analysis showed that Bands 16, 30 and 33 contributed most towards these dissimilarities (Fig. 2A).

\section{Temporal variation}

Temporal variation was investigated at the individual colony and reef levels. There was significant variation in OTUs for temporally-distant samples from individually

\section{RESULTS}

\section{Spatial variation}

DGGE profiles generated for the 5 sites in December 2003 showed a total of 41 OTUs (Fig. 2A), of which 5 (Bands 2, 3, 22, 30 and 31) appeared to be common to all sites. More typically, band presence varied among sites. All sites had 1 to 4 unique OTUs which could potentially be used as indicators for that site. There was a high degree of similarity between samples relative to variation between sites (Fig. 2A). Triplicate samples from 13 corals within a site showed no significant difference between coral heads (1-way ANOSIM, R = 0.119, $\mathrm{p}=0.093$ ). Similarly, there was no difference between coral heads when OTU variation of replicate coral was nested within site (2-way ANOSIM, $R=-0.063, p=0.731$ ). This suggested that a single mucus sample was sufficiently representative of the bacterial community for an individual coral head, and that coral heads from within a site could be considered as sample replicates.

Total OTU diversity was significantly different between sites using ShannonWiener $\left(H^{\prime}\right)$ and Brillouin (HB) diversity indices calculated from relative band intensity data (Fig. 3, Table 1). Relative dominance of band intensities was also

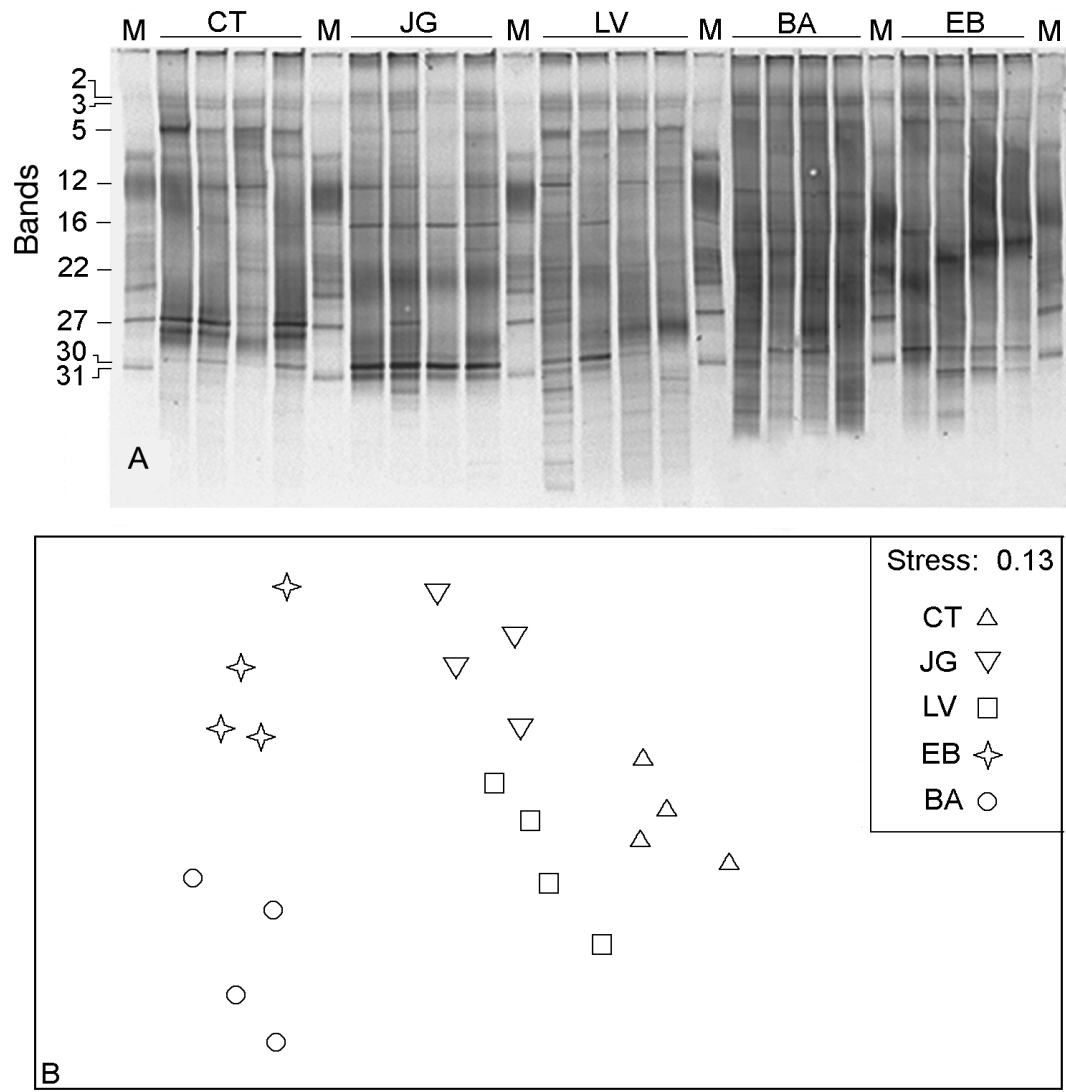

Fig. 2. Variation in 16S rDNA fingerprints within and between sites represented by (A) DGGE gel and (B) multidimensional scaling (MDS) plot. MDS plot generated using Bray-Curtis square root transformation in Primer 5.2 from the band intensity operational taxonomic unit (OTU) matrix from BioNumerics 3.5. (A) Gel composite of DGGE with selected band numbers; M: marker lane. (B) MDS plot showing within- and between-site variation of SML bacterial OTU. Site abbreviations as in Fig. 1 
tagged colonies within the reefs at Cathedral $(\mathrm{n}=3)$ and Englishman's Bay $(n=2)$ over the 3 mo period December to February $(\mathrm{R}=0.278, \mathrm{p}=0.019$ and $\mathrm{R}=0.494, \mathrm{p}=0.003$ respectively), but those from Lucy Vale $(\mathrm{n}=2)$ did not appear to be significantly different $(R=0.223, p=0.060)$. Using tagged coral heads as replicates ( $\mathrm{n}=4 \times 3$ sites), there were strongly significant temporal differences in OTUs from Japanese Gardens, Cathedral and Lucy Vale when these corals were repeatedly sampled covering a single wet (June, August and October) and dry (December, January, February) season cycle. DGGE OTU diversity at a given site over time generally increased from June 2003 to February 2004 (Fig. 4), where a 2-way crossed ANOSIM test (site and month) indicated profound differences in SML bacterial community DGGE profiles at a given site between months $(R=0.711, p=$ 0.001). Although MDS ordination of the temporal data showed some overlap between the DGGE OTU profiles (Fig. 5), there was a difference in profiles between the wet and dry months tested $(\mathrm{R}=0.302, \mathrm{p}=0.001)$.

\section{Environmental influences on bacterial community}

Delivery to the SML

Bacterial delivery to the SML was only considered from the water column. Similar to the SML, DGGE OTU profiles from bacteria in the water column

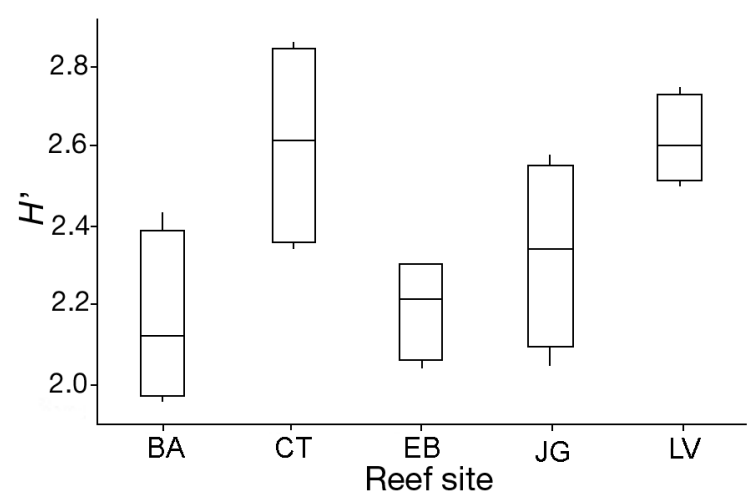

Fig. 3. Boxplot of mean Shannon-Wiener diversity $\left(H^{\prime}\right)$ of DGGE OTUs (based on band intensity) for 5 reef sites with interquartile ranges. Site abbreviations as in Fig. 1 strongly differed both spatially between 5 sites $(\mathrm{n}=5$ per site, ANOSIM, $\mathrm{R}=0.652, \mathrm{p}=0.001$ ) and temporally over 6 mo ( $\mathrm{n}=5$ per site per month, 2-way crossed ANOSIM, $R=0.948, p=0.001)$. There were highly significant differences between DGGE band intensity profiles from the water column $(\mathrm{n}=14)$ and coral SML ( $\mathrm{n}=16$ ) sampled at the same sites (Fig. 6, ANOSIM, $\mathrm{R}=$ $0.74, \mathrm{p}=0.001)$. Although 25 bands (52\%) were common between SML and water filter samples, the water column fingerprint contained 6 bands that were not present on SML fingerprints. Conversely, 17 bands appeared to be unique to the SML samples. There was no relationship in the DGGE profiles from SML and water filters (RELATE, $\rho=0.176, p=0.665$ ), indicating

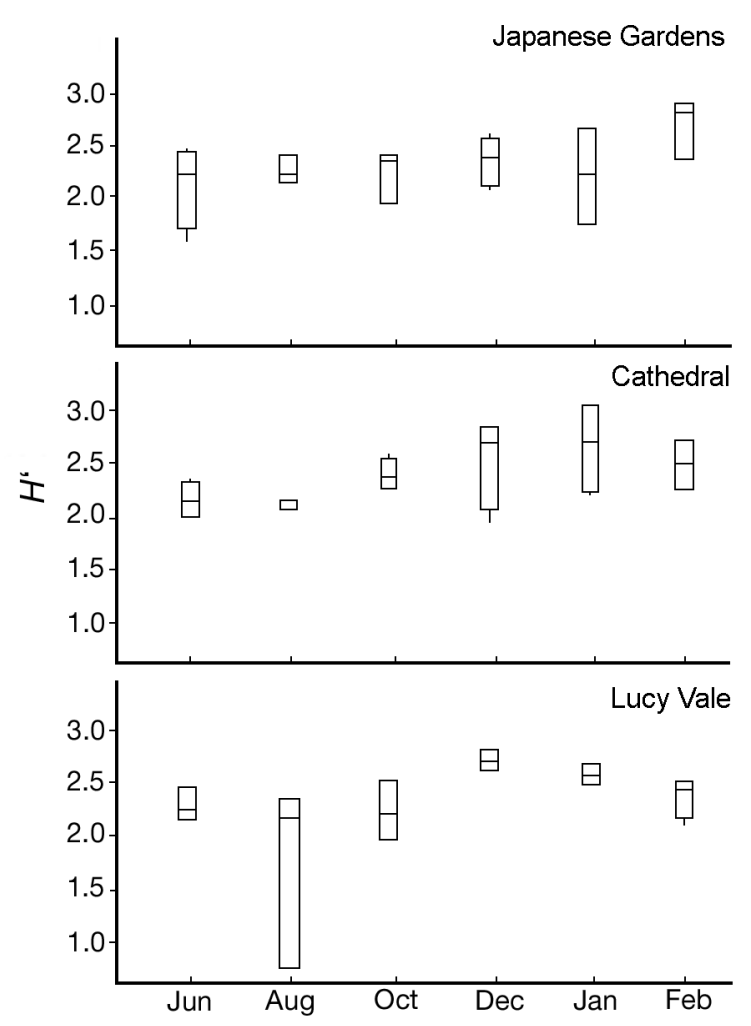

Fig. 4. Temporally-distant variation of DGGE OTU (based on band intensity) from 3 sites within Speyside marine area based on mean Shannon-Wiener diversity $\left(H^{\prime}\right)$ (from June 2003 to February 2004, showing interquartile ranges

Table 1. Diversity and dominance indices based on DGGE OTU (band intensity) data (mean $\pm 95 \%$ confidence interval, $\mathrm{n}=4$ ). Results of 1-way ANOVAs between sites are shown

\begin{tabular}{|c|c|c|c|c|c|c|c|}
\hline \multirow[t]{2}{*}{ Index } & \multirow{2}{*}{ Lucy Vale } & \multirow[b]{2}{*}{ Cathedral } & \multirow{2}{*}{$\begin{array}{l}\text { Site } \\
\text { Englishman's Bay }\end{array}$} & \multirow[b]{2}{*}{ Japanese Gardens } & \multirow[b]{2}{*}{ Batteaux Bay } & \multicolumn{2}{|c|}{ - ANOVA- } \\
\hline & & & & & & $F$ & $\mathrm{p}$ \\
\hline Shannon $\left(H^{\prime}\right)$ & $2.7 \pm 0.18$ & $2.6 \pm 0.47$ & $2.2 \pm 0.24$ & $2.3 \pm 0.46$ & $2.2 \pm 0.42$ & 6.04 & 0.004 \\
\hline Brillouin (HB) & $2.6 \pm 0.17$ & $2.5 \pm 0.45$ & $2.1 \pm 0.22$ & $2.3 \pm 0.44$ & $2.0 \pm 0.41$ & 7.36 & 0.002 \\
\hline Simpson (1-D) & $0.87 \pm 0.064$ & $0.90 \pm 0.054$ & $0.87 \pm 0.025$ & $0.88 \pm 0.054$ & $0.92 \pm 0.018$ & 3.31 & 0.039 \\
\hline
\end{tabular}




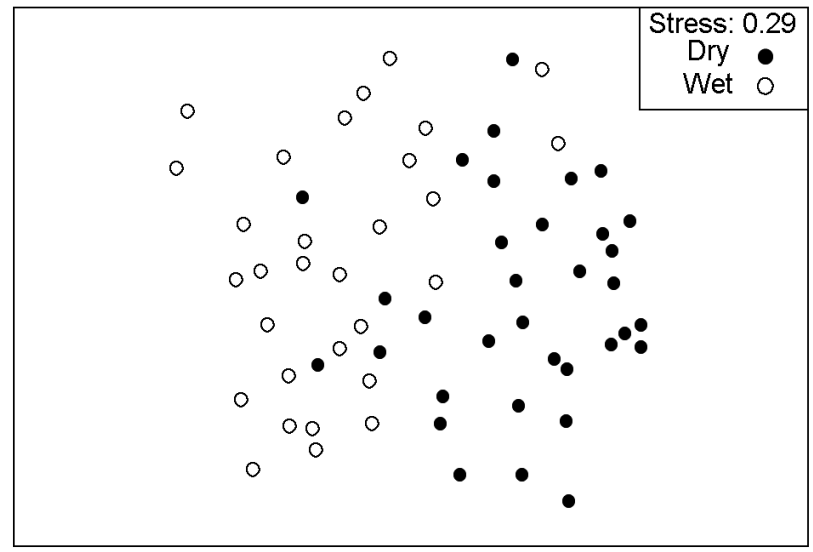

Fig. 5. MDS plot generated from Bray-Curtis similarity matrix after standardisation and square root transformation of OTU matrix showing temporal (wet and dry season) variation for the 3 reef sites (Japanese Gardens, Cathedral, Lucy Vale) combined

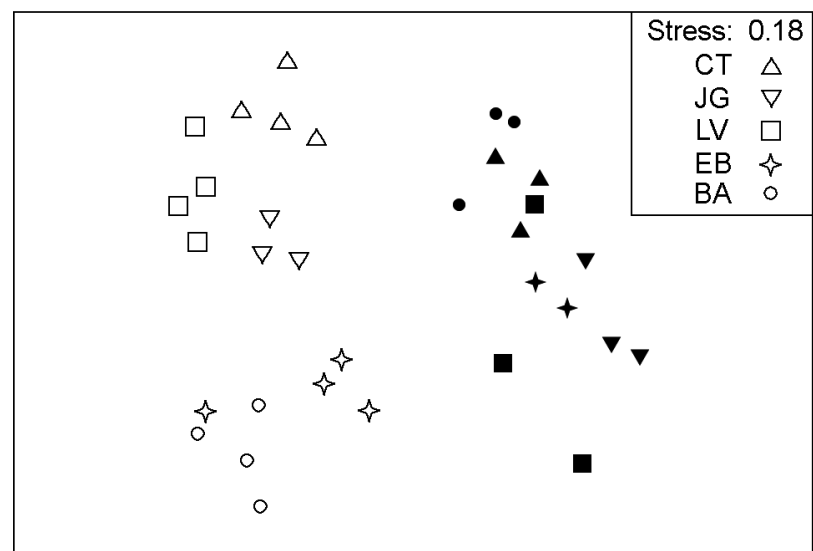

Fig. 6. MDS plot of water-column (black) and surface mucus layer SML (white) bacterial 16S rDNA fingerprints at 5 sites in December, generated from Bray-Curtis similarity after standardisation and square root transformation of OTU matrix. Site abbreviations as in Fig. 1

that the 2 bacterial communities are distinct and that one does not simply represent a subset of the other.

Water quality parameters

Eight environmental variables (chlorophyll $a_{1} \mathrm{NO}_{\mathrm{x}}{ }^{-}$, $\mathrm{PO}_{4}{ }^{3-}$, dissolved $\mathrm{O}_{2}$, turbidity, total coliform, faecal coliform and E. coli counts) were used to determine any relationship between normalised environmental variables and DGGE intensity profiles. In December, Englishman's Bay had the overall highest $\mathrm{NO}_{\mathrm{x}}{ }^{-}$and chlorophyll a levels, and within the Speyside marine area (Fig. 1C), Lucy Vale had the highest $\mathrm{PO}_{4}{ }^{3-}$ and $\mathrm{NO}_{\mathrm{x}}{ }^{-}$ (Fig. 7), but the variability between sites does not suggest the presence of a water quality gradient at adja-

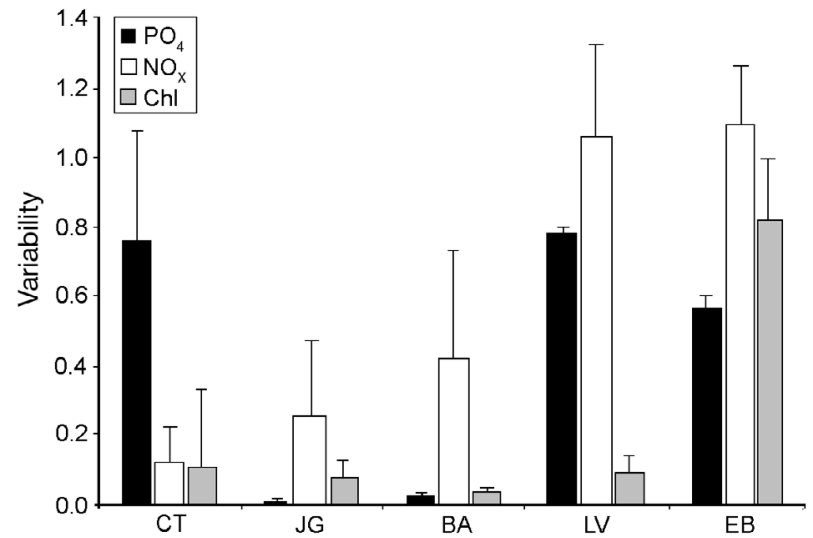

Fig. 7. Variation in water chemistry in December grouped by site, (mean $+95 \%$ confidence limits. $\mathrm{PO}_{4}=$ phosphate ion $\left(\mu \mathrm{mol} \mathrm{l} \mathrm{l}^{-1}\right) ; \mathrm{NO}_{\mathrm{x}}=$ nitrate + nitrite ions $\left(\mu \mathrm{mol} \mathrm{l}^{-1}\right) ; \mathrm{Chl}=$ chlorophyll a $\left(\mathrm{mg} \mathrm{l}^{-1} \times 10^{2}\right)$. Site abbreviations as in Fig. 1

cent sites. Although the different parameters show varying patterns between sites, the environmental variables differed significantly between sites (Fig. 8, MANOVA, Wilks', Lawley-Hotelling, Pillai's tests, p < 0.001). Total DGGE band diversity (Shannon $H^{\prime}$ ) was also not significantly correlated $(\mathrm{R}=-0.47, \mathrm{p}>0.4)$ with an overall measure of water quality (PC1 of the principal components analysis for all water quality variables). When compared with the DGGE band intensity profile, the biota-environment matching programme BIOENV in PRIMER 6.1.5 showed that a 4 -variable combination of chlorophyll $a_{1} \mathrm{PO}_{4}{ }^{3-}$, dissolved $\mathrm{O}_{2}$, and E. coli best explained the similarities observed in the SML fingerprints $(\mathrm{R}=0.576)$. However, there were no obvious relationships between the DGGE profile similarities and any of the individual environmental variables (Fig. 9). Together, these results indicate that although indicator variables of the 5 sites varied significantly, there was no clear gradient in overall water quality and no evidence of a simple relationship between these environmental variables and the $16 \mathrm{~S}$ rDNA DGGE profiles.

\section{DISCUSSION}

Assessing changes in the composition of the bacterial community associated with reef corals offers considerable potential as a bioindicator of the health status of the holobiont and has been successfully used as a health-indicator in other organisms, notably in mammalian gut flora (Guarner \& Malagelada 2003, Lan et al. 2005). Pantos et al. (2003) showed that changes in bacterial community structure may precede the visible appearance of disease signs and therefore represent a sensitive indicator of sublethal physiological condition. We therefore examined the changes in the bacterial 


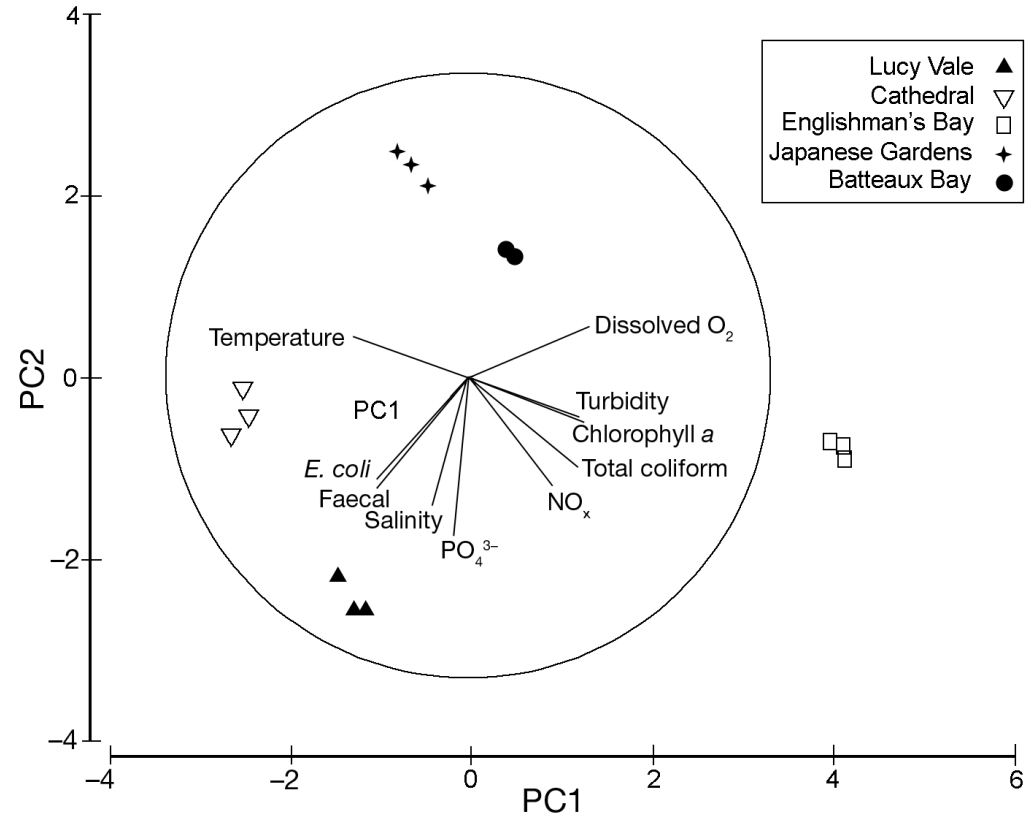

Fig. 8. Principal components analysis (PCA) of normalised data from 10 water quality parameters, where the combined eigenvalues for PC1 and PC 2 are $86 \%$. In eigenvectors, vector length indicates importance of the variable's contribution to PC1 and PC2; circle represents maximum length of vector for a given variable such that all other eigenvector coefficients equal zero

resultant SML microbial community, but consideration of the close proximity of the sites and water currents makes this unlikely.

The profound spatial (reef to reef) and temporal (month to month) patterns in bacterial OTUs may indicate a sensitive response to environmental conditions. Klaus et al. (2005) have also recently shown that reef corals can harbour significantly different bacterial communities between sites subject to varying levels of pollution (as indicated by nitrogen levels in coral tissue), but the response varied between host coral species, with Montastraea annularis (a conspecific of M. faveolata) showing no consistent spatial variation. The present study did not find any clear relationships between the SML bacterial community composition and measured water quality variables or any other environmental variables such as temperature, depth, salinity or proximity to mainland (data not shown). The fact that there is no direct link between the water quality variables and SML community suggests that the water

(16S rRNA gene) community composition (over space and time) in the surface mucus layer (SML) of the reef coral Montastraea faveolata to determine if these communities could potentially be used as a bioindicator for environmental change and/or coral health. The problems and limitations of the PCR-DGGE approach in estimating microbial diversity have been previously discussed (Iwamoto et al. 2000, Eiler et al. 2003, Van der Gucht et al. 2005). However, compared to cloning and sequencing of bacterial genes, which can provide greater detail of bacterial diversity (Rohwer et al. 2001, 2002, Frias-Lopez et al. 2002, Bourne \& Munn 2005), DGGE profiles are an attractive alternative as they allow highly replicated analysis of bacterial communities that is less time-consuming, less costly and less labour-intensive than sequencing (Muyzer et al. 1993). PCR-DGGE is therefore particularly suited to spatial and temporal investigations (Schauer et al. 2000).

There is already strong evidence for species-specific coral-bacterial associations (Frias-Lopez et al. 2002, Rohwer et al. 2002, Rohwer \& Kelley 2004, Bourne \& Munn 2005), which may indicate important physicochemical interactions. However, focusing on a single species, we found strong intraspecific variation $(\mathrm{p}=$ 0.001 ) between sites. It could be that these site-specific differences may be due to a spatial variation in coral genotype (Knowlton et al. 1997, Szmant et al. 1997) which would affect the SML composition and the chemistry dynamics in the study area are extremely complex and cannot be accurately described by point sampling. All 5 sites are in areas with strong water currents and relatively high flushing rates (IMA 2002). Tobago's waters are heavily influenced by large-scale effects of the Orinoco plume from Venezuela during the wet season, as well as influxes of nutrient-rich and lowsalinity water from local run-off and vertical mixing (Bonilla et al. 1993, Del Castillo et al. 1999, Warne et al. 2002). The different sites are therefore characterised by variable levels of different nutrients and other water quality indicators, which may reflect the variable influence of local and regional processes. Also, any changes in the SML bacterial community may not reflect the water chemistry at the point of sampling, due to a lag effect-either as a biofilm or due to mucus sloughing. The spatial and temporal variation observed represents a highly sensitive, deterministic relationship with environmental conditions, but this relationship is hidden by the complex nature of the environment.

In addition to the possible SML differences arising from genetic variability and complex environmental interactions, the question of differences in the delivery of bacteria to the coral SML needs to be addressed. Possible delivery sources include (1) transference from predators and faecal matter, and (2) bacterial populations in the water column, which may act as the ultimate source of bacteria to the SML via passive trans- 


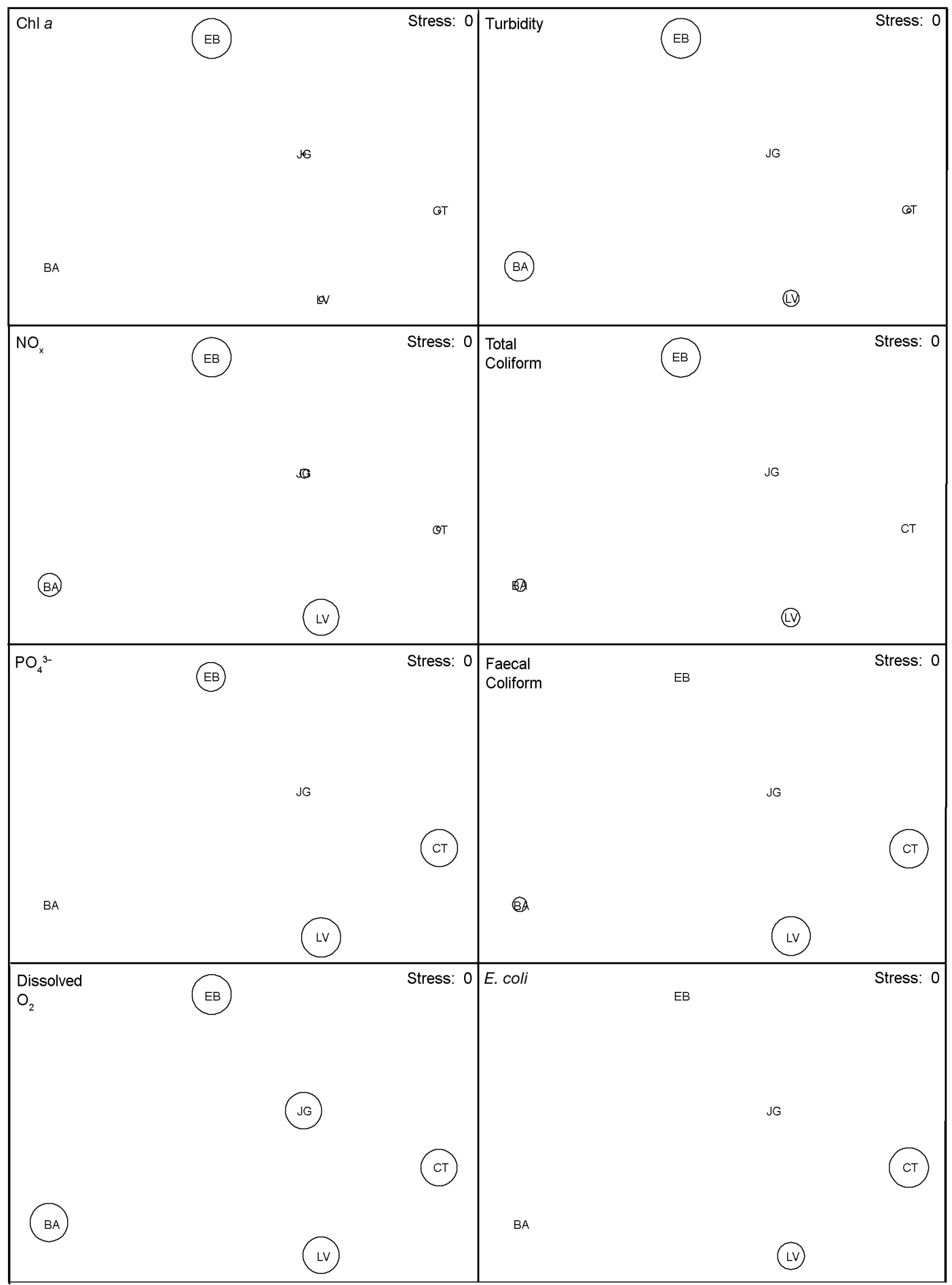

Fig. 9. Bubble plots showing relationship between various environmental variables and MDS plot of DGGE OTU similarity averaged by site. Diameter of the circles represents the level of the variable. Site abbreviations as in Fig. 1 
port. Although only the water column was targeted in the present study, the lack of variability between samples taken from the same coral head does suggest that transference may not be a major source of bacteria to the SML. The reef coral SML environment is characterised by high levels of fixed carbon flow (Ritchie \& Smith 2005) and productivity (Paul et al. 1986) and is highly dynamic, although the rate of mucus secretion and turnover of the SML under natural conditions in situ is unknown (Brown \& Bythell 2005). Despite this, the SML appears to host a distinct, resident microbial flora and this study supports previous findings that showed distinct differences in the community structure of water column versus coral-associated bacteria (Rohwer et al. 2001, Frias-Lopez et al. 2002). The composition of secreted mucus varies considerably between coral species (Brown \& Bythell 2005) and mucus secretions may change during coral bleaching (Ducklow \& Mitchell 1979a,b, Ritchie et al. 1995a,b) and various other stress conditions. The microbial flora of the SML might therefore be expected to respond both directly to changes in environment and indirectly due to environmental effects on host physiology, and could therefore help explain the spatial and temporal differences in microbial community structure shown here. The question remains, therefore, whether the spatial and temporal variations seen here are indicative of predictable, deterministic relationships with the SML environment or stochastic processes dependent on the rate of SML turnover and colonisation of bacteria from the water column (Simberloff 1978, Manefield et al. 2005). Further work is needed to establish the relative importance of stochastic versus deterministic processes in the assembly of the SML microbial community.

In contrast to Montastraea annularis (Klaus et al. 2005), the clear spatial and temporal patterns for M. faveolata could potentially be useful as a bioindicator for environmental change; however, a more complete understanding of variability in the bacterial community of healthy corals is clearly needed before we can assess the environmental factors controlling that variation. Revisiting tagged corals more often and for longer sampling periods would enable us to determine whether or not the temporal variability is cyclical. Also, sequencing of the common and unique bacterial OTUs is necessary to confirm that these OTUs are indeed the same bacteria and not different bacteria that have migrated to a similar position in the DGGE gel.

Acknowledgements. This work was supported in part by an ISRS/TOC fellowship and Leverhulme Grant F/00 1125/S. The authors thank R. Caesar, Frontier Divers, Redman M. Dives, and the Buccoo Reef Trust for assistance and logistical support while in Tobago. We are also grateful to R. Davenport for use of the BioNumerics programme in IRES, University of Newcastle.

\section{LITERATURE CITED}

Ausubel FM (1999) Short protocols in molecular biology: a compendium of methods from current protocols in molecular biology, 4th edn. Wiley \& Sons, New York

Bonilla J, Senior W, Bugden J, Zafiriou O, Jones R (1993) Seasonal distribution of nutrients and primary productivity of the eastern continental shelf of Venezuela as influenced by the Orinoco River. J Geophys Res 98:2245-2257

Bourne DG, Munn CB (2005) Diversity of bacteria associated with the coral Pocillopora damicornis from the Great Barrier Reef. Environ Microbiol 7:1162-1174

Brown B, Bythell JC (2005) Perspectives on mucus secretion in reef corals. Mar Ecol Prog Ser 296:291-309

Bythell JC, Barer MR, Cooney RP, Guest JR, O'Donell AG, Pantos O, Le Tissier MDA (2002) Histopathological methods for the investigation of microbial communities associated with disease lesions in reef corals. Lett Appl Microbiol 34:359-364

Clarke KR, Warwick RM (1994) Change in marine communities: an approach to statistical analysis and interpretation. Natural Environment Research Council, Swindon

Cooney R, Pantos O, Le Tissier MDA, Barer MR, O'Donnell AG, Bythell JC (2002) Characterization of the bacterial consortium associated with black band disease in corals using molecular microbiological techniques. Environ Microbiol 4:401-413

Del Castillo CE, Coble PG, Morell JM, López JM, Corredor JE (1999) Analysis of the optical properties of the Orinoco River plume by absorption and fluorescence spectroscopy. Mar Chem 66:35-51

Ducklow HW, Mitchell R (1979a) Composition of mucus released by coral reef coelenterates. Limnol Oceanogr 24: 706-714

Ducklow HW, Mitchell R (1979b) Bacterial populations and adaptations in the mucus layers on living corals. Limnol Oceanogr 24:713-725

Eiler A, Langenheder S, Bertilsson S, Tranvik LJ (2003) Heterotrophic bacterial growth efficiency and community structure at different natural organic carbon concentrations. Appl Environ Microbiol 69:3701-3709

Frias-Lopez J, Zerkle AI, Bonheyo GT, Fouke BW (2002) Partitioning of bacterial communities between seawater and healthy, black band diseased, and dead coral surfaces. Appl Environ Microb 68:2214-2228

Guarner F, Malagelada JR (2003) Gut flora in health and disease. Lancet 361:512-519

Harder T, Lau SCK, Dobretsov S, Fang TK, Qian PY (2003) A distinctive epibiotic bacterial community on the soft coral Dendronephthya sp. and antibacterial activity of coral tissue extracts suggest a chemical mechanism against bacterial epibiosis. FEMS Microbiol Ecol 43:337-347

Harvell CD, Mitchell CE, Ward JR, Altizer S, Dobson AP, Ostfeld RS, Samuel MD (2002) Climate warming and disease risks for terrestrial and marine biota. Science 296: $2158-2162$

Hoegh-Guldberg O (1999) Climate change, coral bleaching and the future of the world's coral reefs. Mar Freshw Res 50:839-866

IMA (Institute of Marine Affairs) (2002) Biophysical technical report for the formulation of a management plan for Speyside Reef Marine Park. Document prepared for the Tobago House of Assembly. Institute of Marine Affairs, Chaguaramas, Trinidad

Iwamoto T, Tani K, Nakamura K, Suzuki Y, Kitagawa M, Eguchi M, Nasu M (2000) Monitoring impact of in situ biostimulation treatment on groundwater bacterial com- 
munity by DGGE. FEMS Microbiol Ecol 32:129-141

Jordán-Dahlgren E, Maldonado MA, Rodríguez-Martínez R (2005) Diseases and partial mortality in Montastraea annularis species complex in reefs with differing environmental conditions (NW Caribbean and Gulf of México). Dis Aquat Org 63:3-12

Kellogg CA (2004) Tropical Archaea: diversity associated with the surface microlayer of corals. Mar Ecol Prog Ser 273:81-88

Klaus JS, Frias-Lopez J, Bonheyo GT, Heikoop JM, Fouke BW (2005) Bacterial communities inhabiting the healthy tissues of two Caribbean reef corals: interspecific and spatial variation. Coral Reefs 24: 129-137

Knowlton N, Maté JL, Guzmán HM, Rowan R, Jara J (1997) Direct evidence for reproductive isolation among the three species of the Montastraea annularis complex in Central America (Panamá and Honduras). Mar Biol 127:705-711

Lan Y, Verstegen MWA, Tamminga S, Williams BA (2005) The role of the commensal gut microbial community in broiler chickens. World's Poult Sci J 61:95-104

Manefield M, Griffiths RI, Leigh MB, Fisher R, Whiteley AS (2005) Functional and compositional comparison of two activated sludge communities remediating coking effluent. Environ Microbiol 7:715-722

Manini E, Luna EM, Danovaro R (2004) Benthic bacterial response to variable estuarine water inputs. FEMS Microbiol Ecol 50:185-194

Muyzer G, De Waal EC, Uitterlinden AG (1993) Profiling of complex microbial populations by denaturing gradient gel electrophoresis analysis of polymerase chain reactionamplified genes coding for 16S rRNA. Appl Environ Microbiol 59:695-700

Paerl HW, Dyble J, Moisander PH, Noble RT and 5 others (2003) Microbial indicators of aquatic ecosystem change: current applications to eutrophication studies. FEMS Microbiol Ecol 46:233-246

Pantos O, Cooney RP, Le Tissier MDA, Barer MR, O'Donnell AG, Bythell JC (2003) The bacterial ecology of a plaguelike disease affecting the Caribbean coral Montastrea annularis. Environ Microbiol 5:370-382

Parsons TR, Maita Y, Lalli CM (1984) A manual of chemical and biological methods for seawater analysis. Pergamon Press, New York

Paul JH, DeFlaun MF, Jeffrey WH (1986) Elevated levels of microbial activity in the coral surface microlayer. Mar Ecol Prog Ser 33:29-40

Ritchie KB, Smith GW (1995a) Preferential carbon utilization by surface bacterial communities from water mass, normal, and white-band diseased Acropora cervicornis. Mol Mar Biol Biotechnol 4:345-352

Ritchie KB, Smith GW (1995b) Carbon-source utilization patterns of coral-associated marine heterotrophs. J Mar

Editorial responsibility: Howard Browman (Associate Editorin-Chief), Storebø, Norway
Biotechnol 3:105-107

Ritchie KB, Smith GW (1997) Physiological comparison of bacterial communities from various species of scleractinian corals. Proc 8th Int Coral Reef Symp 1:521-526

Ritchie KB, Smith GW (2005) Microbial communities of coral surface mucopolysaccharide layers. In: Rosenberg E, Loya Y (eds) Coral health and disease. Springer-Verlag, Berlin, p 259-264

Rohwer F, Kelley S (2004) Culture-independent analyses of coral-associated microbes. In: Rosenberg E, Loya Y (eds) Coral health and disease. Springer-Verlag, Berlin, p 265-277

Rohwer F, Breitbart M, Jara J, Azam F, Knowlton N (2001) Diversity of bacteria associated with the Caribbean coral Montastraea franksi. Coral Reefs 20: 85-91

Rohwer F, Seguritan V, Azam F, Knowlton N (2002) Diversity and distribution of coral-associated bacteria. Mar Ecol Prog Ser 243:1-10

Rölleke S, Muyzer G, Wawer C, Wanner G, Lubitz W (1996) Identification of bacteria in a biodegraded wall painting by denaturing gradient gel electrophoresis of PCR-amplified gene fragments coding for 16S rRNA. Appl Environ Microbiol 62:2059-2065

Rosenberg E, Ben-Haim Y (2002) Microbial diseases of corals and global warming. Environ Microbiol 4:318-326

Santavy DL (1995) The diversity of micoorganisms associated with marine invertebrates and their roles in the maintenance of ecosystems. CAB International, Wallingford

Schauer M, Massana R, Pedrós-Alió C (2000) Spatial differences in bacterioplankton composition along the Catalan coast (NW Mediterranean) assessed by molecular fingerprinting. FEMS Microbiol Ecol 33:51-59

Simberloff D (1978) Using island biogeographic distributions to determine if colonization is stochastic. Am Nat 112: 713-726

Strickland JDH, Parsons TR (1968) Determination of reactive nitrate. In: A practical handbook of seawater analysis. Bull Fish Res Board Can 167:71-75

Suzuki MT, Giovannoni SJ (1996) Bias caused by template annealing in the amplification of mixtures of 16S rRNA genes by PCR. Appl Environ Microbiol 62:625-630

Szmant AM, Weil E, Miller MW, Colon DE (1997) Hybridization within the species complex of the scleractinian coral Montastraea annularis. Mar Biol 129:561-572

Van der Gucht K, Vandekerckhove T, Vloemans N, Cousin S and 6 others (2005) Characterization of bacterial communities in four freshwater lakes differing in nutrient load and food web structure. FEMS Microbiol Ecol 53:205-220

Warne AG, Meade RH, White WA, Guevara EH, Gibeaut J, Smyth RC, Aslan A, Tremblay T (2002) Regional controls on geomorphology, hydrology, and ecosystem integrity in the Orinoco Delta, Venezuela. Geomorphology 44:273-307

Submitted: November 24, 2005; Accepted: May 11, 2006 Proofs received from author(s): December 4, 2006 